\title{
dorsal-twist interactions establish snail expression in the presumptive mesoderm of the Drosophila embryo
}

\author{
Y. Tony Ip, ${ }^{1}$ Ronald E. Park, ${ }^{1}$ David Kosman, ${ }^{1}$ Karina Yazdanbakhsh, ${ }^{2}$ and Michael Levine ${ }^{1}$ \\ ${ }^{1}$ Biology Department, Center for Molecular Genetics, University of California at San Diego, La Jolla, California 92093-0322 \\ USA; $^{2}$ Department of Biological Sciences, Fairchild Center, Columbia University, New York, New York 10027 USA
}

The first step in the differentiation of the Drosophila mesoderm is the activation of two regulatory genes, twist (twi) and snail (sna), in ventral regions of early embryos. sna is a transcriptional repressor that is uniformly expressed throughout the presumptive mesoderm. Its sharp lateral limits help to establish the boundary between the mesoderm and neuroectoderm. Genetic studies suggest that sna is a target of the dorsal (dI) morphogen, and this interaction provides a model for determining how a morphogen gradient establishes a sharp, on/off threshold response. We present evidence that $d l$ and twi directly activate sna expression.

Site-directed mutagenesis of $\boldsymbol{d l}$ - and twi-binding sites within defined regions of the sna promoter suggest that the two proteins (containing the Rel and helix-loop-helix domains, respectively) function multiplicatively to ensure strong, uniform expression of sna, particularly in ventral-lateral regions where there are diminishing amounts of $\boldsymbol{d l}$. These results are consistent with the possibility that the sharp sna borders are formed by multiplying the shallow $d l$ gradient and the steeper $t$ wi gradient.

[Key Words: Drosophila mesoderm; dorsal-twist interactions; snail expression]

Received April 30, 1992; revised version accepted June 5, 1992.

A cascade of maternally active genes results in the regulated nuclear transport of the dorsal (dl) morphogen in the early Drosophila embryo (Roth et al. 1989; Rushlow et al. 1989; Steward 1989; for review, see St. Johnston and Nüsslein-Volhard 1992). The $d l$ protein is initially distributed throughout the cytoplasm of unfertilized eggs and early embryos, but protein present in ventral regions enters the nuclei $\sim 90 \mathrm{~min}$ after fertilization. An as yet uncharacterized cue in ventral regions of the perivitelline fluid stimulates the Toll receptor which, in turn, results in nuclear transport (Hashimoto et al. 1988; Stein et al. 1991). This local activation of Toll triggers a subcellular gradient of $d l$, such that protein in ventral regions is predominantly nuclear, while it is mainly cytoplasmic in dorsal regions. The protein is equally partitioned between cytoplasm and nuclei in lateral regions. This gradient in nuclear transport gives rise to an absolute gradient by cellularization, such that there are overall higher levels of the protein in ventral versus dorsal regions. In this report we consider how the $d l$ concentration gradient establishes different territories of gene expression along the dorsal-ventral axis.

dl functions as a sequence-specific DNA-binding protein that directly regulates the transcription of zygotic target genes (for review, see Govind and Steward 1991; Ip and Levine 1992). The two best characterized targets are zerknüllt (zen) and twist (twi). zen encodes a homeo box protein that is required for the differentiation of the am- nioserosa (Doyle et al. 1986; Rushlow et al. 1987), an embryonic tissue that arises from the dorsal ectoderm. $z e n$ is initially expressed in the dorsal half of the embryo but is derepressed throughout ventral regions of mutant embryos derived from $\mathrm{dl}^{-}$mothers. The cis-regulatory element that keeps zen off in ventral regions maps $\sim 1.3$ $\mathrm{kb}$ upstream from the transcription start site (Doyle et al. 1989|. This ventral repression element contains four dl-binding sites, and mutations in these sites cause ventral expression, similar to the derepression of the pattern observed in $\mathrm{dl}^{-}$mutants (Ip et al. 1991; Jiang et al. 1992). Thus, $d l$ appears to directly repress zen transcription, and there is genetic evidence that it may also repress other target genes, including decapentaplegic $(d p p)$ and tolloid (tId) (St. Johnston and Gelbart 1987; Ray et al. 1991; Shimell et al. 1991).

Although both high levels of $d l$ in ventral regions and low levels in lateral regions repress zen, only high levels are sufficient to activate twi. Recent studies have identified a number of $d l$-binding sites in the $t w i$ promoter, and at least several of these are required for activation (Jiang et al. 1991; Pan et al. 1991; Thisse et al. 1991). The affinities of these binding sites are at least fivefold lower than those present in the zen promoter (Jiang et al. 1991; Thisse et al. 1991), which suggests that binding affinities play an important role in establishing the dorsal-ventral limits of target gene expression. The high-affinity sites in the zen promoter permit repression in lateral regions 
where there are low levels of $d l$, whereas the low-affinity sites in twi restrict expression to ventral regions where there are high levels. It is not known how $d l$ functions as both a repressor of zen and an activator of $t w i$, although there is evidence that $d l$ might interact with different neighboring factors in the zen and twi promoters (Doyle et al. 1989; Pan et al. 1991).

$t w i$ acts in concert with a second regulatory gene, snail $(s n a)$, to initiate the differentiation of the mesoderm (Boulay et al. 1987; Thisse et al. 1987; Leptin and Grunewald 1990). Mutations in either gene cause a similar failure of ventral furrow formation and loss of mesoderm. twi and sna are expressed in overlapping but noncoincident patterns in the early embryo (Alberga et al. 1991; Kosman et al. 1991; Leptin 1991). twi is expressed in a graded fashion, with peak levels present in ventral regions and progressively lower levels in ventrallateral regions. Expression extends into the presumptive mesectoderm and includes at least the ventral-most cells of the neuroectoderm. In contrast, sna expression abruptly ends at the lateral limits of the presumptive mesoderm. Double-staining studies indicate that these sharp sna borders coincide with the boundary between the mesoderm and neuroectoderm (Kosman et al. 1991). Another difference between the sna and twi patterns is that sna is not graded but, instead, is uniformly expressed throughout the presumptive mesoderm. The establishment of the sharp sna pattern represents a critical early step in the differentiation of the embryonic mesoderm.

Genetic studies suggest that $t w i$ and sna play different roles in mesoderm formation (Kosman et al. 1991; Leptin 1991). twi encodes a basic helix-loop-helix protein that appears to function primarily as a transcriptional activator (Thisse et al. 1988; Murre et al. 1989), and in $t w i^{-}$ mutants there is a failure to activate genes required for mesoderm differentiation, such as the Drosophila homolog of MyoD (nautilus) (Michelson et al. 1990). In contrast, sna encodes a zinc finger protein (Boulay et al. 1987) that functions mainly as a repressor. sna restricts the expression of a number of mesectodermal and neuroectodermal regulatory genes to lateral regions of the early embryo. These include lethal of scute (T3), rhomboid (rho), single-minded (sim), and genes of the Enhancer of split complex (Nambu et al. 1990; Kosman et al. 1991; Rao et al. 1991). In $s n a^{-}$mutants these genes are expressed in both lateral and ventral regions. Recent evidence suggests that the sharp lateral limits of sna expression define the mesoderm/neuroectoderm boundary by directly repressing one or more of these genes (Kasai et al. 1992). Disruptions in sna-binding sites present in the rho promoter cause otherwise normal rho-lacZ fusion genes to be expressed in both lateral and ventral regions (Ip et al. 1992). Thus, an early step in mesoderm formation is the activation of sna, which functions to exclude an alternative pathway of differentiation (mesectoderm/neuroectoderm).

Previous genetic studies have implicated $d l$ and $t w i$ as the key activators of sna expression. sna is not initiated in $\mathrm{dl}^{-}$mutants, and there is a severe reduction in the levels of sna expression in $t w i^{-}$mutants (Kosman et al. 1991; Ray et al. 1991). dl and twi function in a dosagesensitive manner to activate sna, because there is a narrowing of the sna pattern in embryos that contain half the amount of $d l$ and $t w i$ proteins $(d l /+, t w i)+$ double heterozygotes) (Kosman et al. 1991). The simplest model for sna regulation is that the $d l$ gradient is the primary activator of both twi and sna. twi then acts in concert with $d l$ to drive optimal expression of sna.

In an effort to determine how $d l$ and twi regulate sna we have performed a detailed analysis of its promoter. We present evidence that $d l$ and $t w i$ directly activate sna transcription. Activation by $d l$ depends on a distal promoter element, located between $-1.9 \mathrm{~kb}$ and $-900 \mathrm{bp}$, which contains a total of $10 \mathrm{dl}$-binding sites. The sequential removal of these $d l$ sites causes a progressive narrowing and eventual loss of the pattern. twi binds to a proximal-promoter element located between -250 and $-50 \mathrm{bp}$ and augments sna expression. This regulation by twi is important for high levels of sna expression in ventral-lateral regions where there are diminishing amounts of $\mathrm{dl}$. Site-directed mutagenesis of the $\mathrm{dl}$ - and twi-binding sites suggests that the two proteins function multiplicatively to ensure strong, uniform levels of sna expression throughout the presumptive mesoderm.

\section{Results}

\section{Genetic regulation of the early sna pattern}

In situ hybridization assays suggest that twi and sna are activated at about the same time during embryogenesis, by the onset of nuclear cycle 13 (Thisse et al. 1988; Alberga et al. 1991; Kosman et al. 1991; Leptin 1991). sna RNAs are initially expressed at low levels in the ventralmost 12-14 nuclei (Fig. 1A). The sna pattern becomes quite intense by the onset of nuclear cycle 14 and includes 18 nuclei, but the lateral limits are still fuzzy (Fig. 1B). By mid-cycle 14, the pattern becomes strong and uniform throughout the presumptive mesoderm and exhibits the characteristic sharp boundary (Fig. 1C, arrow). Previous studies have shown that this mature pattern fails to form in $t w i^{-}$embryos (Kosman et al. 1991; Ray et al. 1991). An altered sna pattern can be seen by midcycle 14 (Fig. 1F; cf. with C). There is a failure to activate expression in ventral-lateral regions, and the overall levels of staining remain low. Only the ventral-most 12-14 cells are stained, and the lateral borders remain fuzzy (Fig. 1F, arrow).

The $d l$ morphogen has been implicated as an activator of sna because mutant embryos derived from $\mathrm{dl}^{-}$mothers lack sna RNA and protein. To obtain additional evidence that $d l$ is important for the initiation of sna, we have examined the expression of a "sensitized" sna-lacZ fusion gene in $\mathrm{dl}^{-} / \mathrm{dl} l^{+}$heterozygotes. This sensitized sna promoter is truncated and lacks several $d l$-binding sites (see below). It does not direct a completely authentic sna pattern, although the levels of expression are essentially normal. The staining pattern is restricted to the ventral-most 12-14 cells, and the lateral limits are jagged 


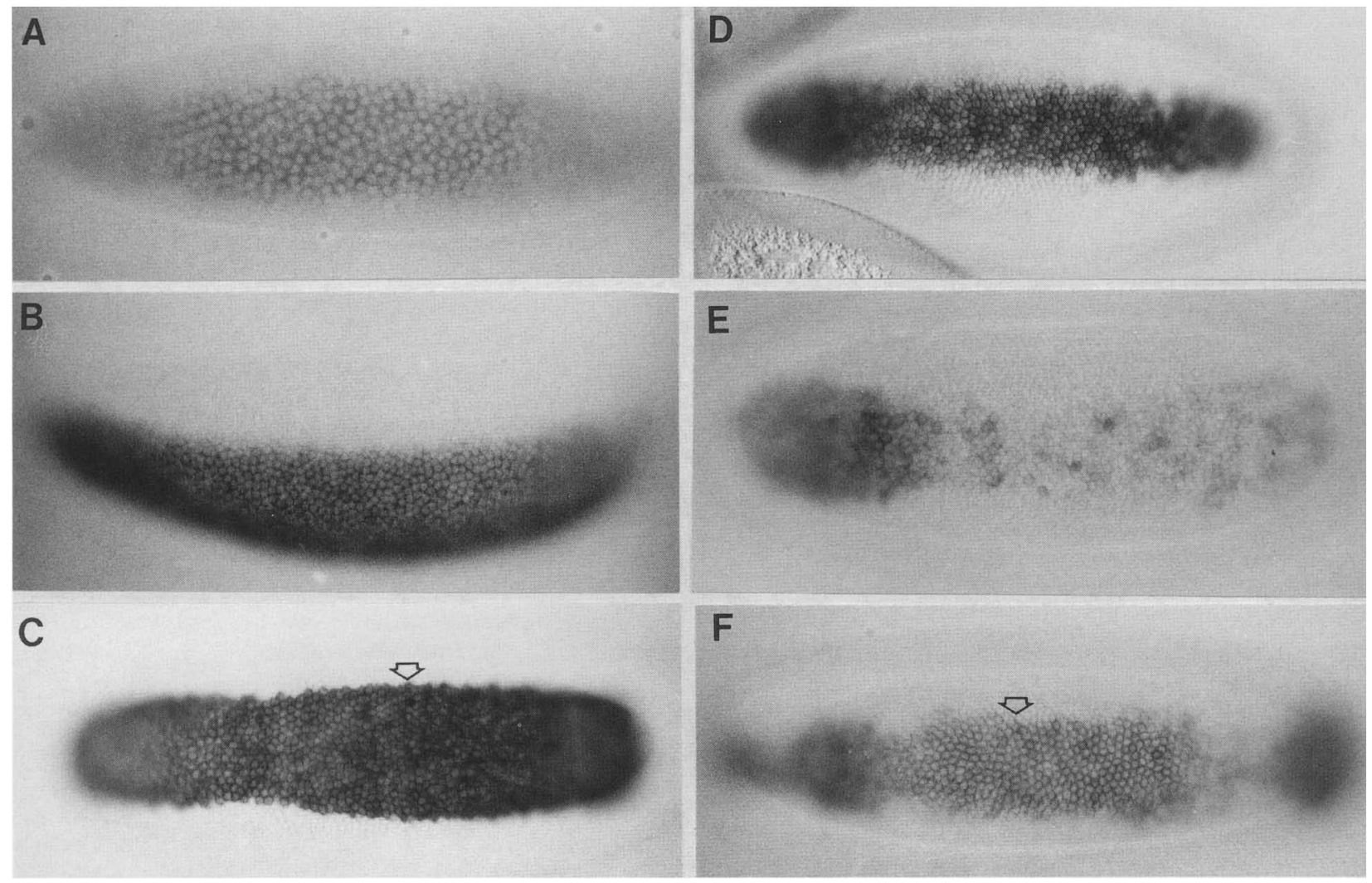

Figure 1. $d l$ and twi activate sna. All embryos are oriented with anterior to the left and display ventral views, except for $B$, which shows a lateral view. (A) Wild-type nuclear cycle 13 embryo showing the sna RNA pattern. The levels of expression are low and the limits are fuzzy. $(B)$ Lateral view of an embryo at the onset of nuclear cycle 14. There are increased levels of sna RNA and the limits include $\sim 18$ cells; however, the borders are still fuzzy. (C) Wild-type cellularizing embryo showing the sna RNA expression pattern. It includes the ventral-most 18 cells, with homogeneous staining throughout the presumptive mesoderm. Staining ends abruptly at the boundary between the mesoderm and neuroectoderm (arrow). (D) Precellular P transformant expressing a sensitized sna-lac $Z$ fusion gene (A1.6, see Fig. 2). The staining pattern was determined by hybridizing the embryo with a lacZ antisense RNA probe, followed by histochemical staining. This sna promoter fragment lacks some of the $d l$-binding sites present in the full-length promoter and, as a result, directs a narrower pattern of expression (just 12 cells rather than 18 cells). However, the levels of expression are essentially normal. (E) A precellular embryo derived from a $d l^{+} / d l^{-}$heterozygous female carrying the same sna-lacZ fusion gene shown in $D$. There is a dramatic disruption of reporter gene expression, suggesting that $d l$ might play a direct role in activating sna expression. $(F)$ sna expression pattern in a precellular $t w i^{-}$embryo. There is a severe reduction in the levels of expression, and the lateral borders are fuzzy (arrow). The staining pattern is narrower than normal and includes just 12-14 cells. There is an even more dramatic reduction in the levels of expression in slightly older embryos (Kosman et al. 1991).

(Fig. 1D; cf. with C). When this sna promoter is expressed in eggs obtained from $d l$ heterozygotes, there is a dramatic reduction in the levels of expression (Fig. 1E). In addition, the residual pattern has a salt-and-pepper appearance, such that neighboring cells display all or no levels of staining. Because $d l$ heterozygotes show no detectable change in twi staining (data not shown), this result suggests that $d l$ might directly activate sna expression.

\section{5'-Flanking sequences direct an essentially normal sna pattern}

The expression patterns of various sna promoter $-1 a c Z$ fusion genes were examined in P-transformed embryos, as summarized in Figure 2. The largest of this series of fusions contains $6 \mathrm{~kb}$ of $5^{\prime}$-flanking sequence, whereas the smallest includes only the proximal-most $250 \mathrm{bp}$ of the promoter. $l a c Z$ fusion genes containing either 6 or $2.8 \mathrm{~kb}$ of the sna promoter display patterns of expression that are nearly identical to the endogenous sna gene, although the expression levels obtained with the $2.8-\mathrm{kb}$ fusion are somewhat reduced as compared with the 6-kb fusion. Reporter gene expression was assayed in wholemount preparations of P-transformed embryos by use of a digoxygenin-UTP-labeled $l a c Z$ antisense RNA probe. Expression is first detected in nuclear cleavage cycle 13 embryos (data not shown), and staining coincides with the presumptive mesoderm by cycle 14 (Fig. 3A). The lateral limits are sharp (Fig. 3A, open arrow), but perhaps not quite as sharp as the endogenous sna RNA pattern (see Fig. 1C). Staining extends throughout the poles (ar- 


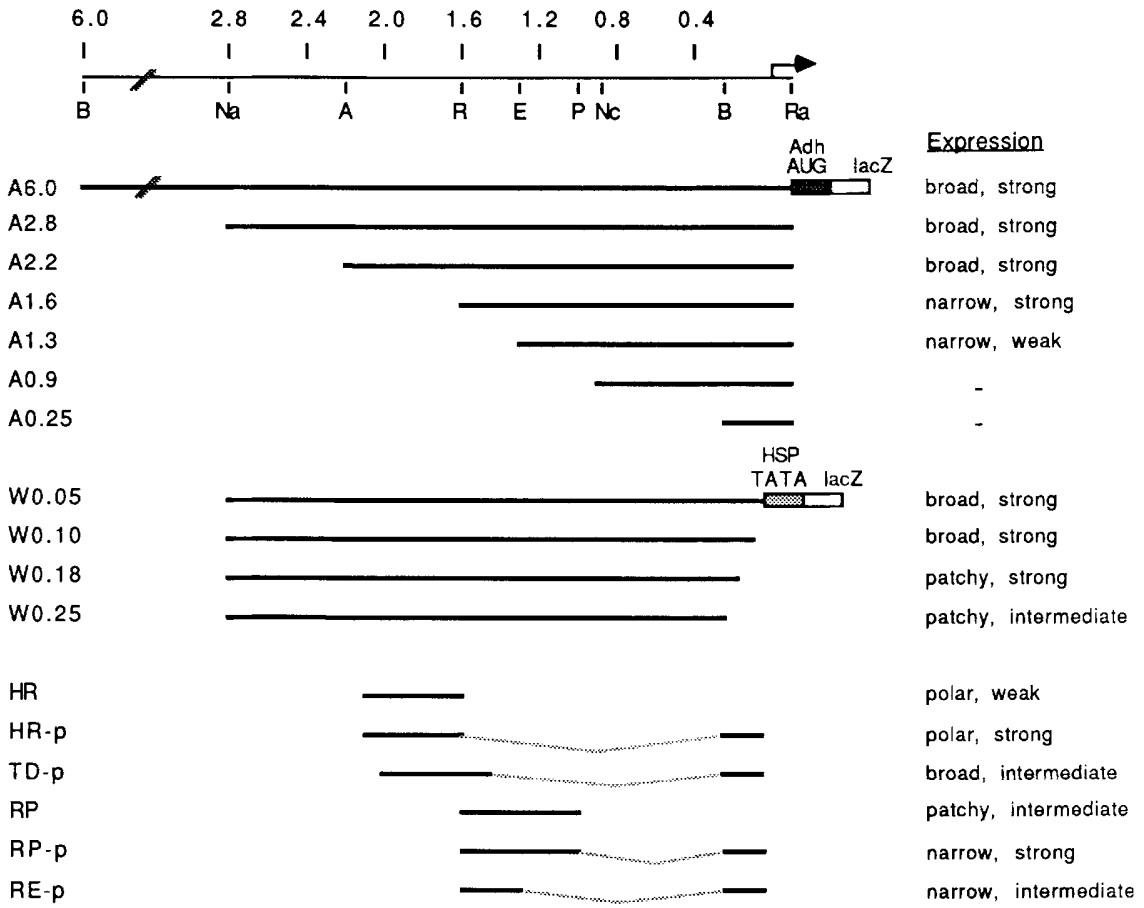

Figure 2. Summary of sna-lacZ fusion genes. The first set of seven fusion genes was prepared by sequentially deleting $5^{\prime}$ sequences of the sna promoter. These fragments were inserted into the pCaSperAUGbetagal P-transformation vector (Thummel et al. 1988). The second and third sets of promoter fusions were placed upstream of the HSP70 minimal promoter in the pWHL transformation vector. The restriction sites of the $5^{\prime}$ series are $6.0 \mathrm{~kb}$, BamHI; $2.8 \mathrm{~kb}$, Nael; $2.2 \mathrm{~kb}$, AccI; $1.6 \mathrm{~kb}$, EcoRV; $1.3 \mathrm{~kb}, E c o R I ; 0.9 \mathrm{~kb}, N c o I ; 0.25$ $\mathrm{kb}$, BamHI. The 3 ' deletions /second series) contain the same $5^{\prime}$ site (NaeI at -2.8 kb). The $3^{\prime}$ restriction sites are AhaII, -50 bp; PflMI, - 100 bp; BspMI, - 180 bp; BamHI, -250 bp. The HR construct includes a $400-b p$ HincII-EcoRV sna promoter fragment, which spans the region from -2.0 to $-1.6 \mathrm{~kb}$. This fragment was inserted into both the pWHL vector containing only the heterologous HSP70 promoter (HR) and the same vector containing the proximal $250 \mathrm{bp}$ of the sna promoter (HR-p). (TD-p) A 400-bp PstI-DraI sna fragment (from -1.9 to $-1.5 \mathrm{~kb}$ ) that

was placed in the pWHL vector with the 250-bp sna proximal region. (RP) A 600-bp EcoRV-PvuII fragment ( -1.6 to $-1.0 \mathrm{~kb}$ ), that was placed either in pWHL alone or in the vector with proximal sna promoter sequences (RP-p). (RE-p) A 300-bp EcoRV-EcoRI fragment $(-1.6$ to $-1.3 \mathrm{~kb}$ ) placed in the pWHL vector with the proximal promoter. (p) Proximal promoter sequences from -250 to $-50 \mathrm{bp}$. The expression levels and patterns are indicated at right. The broad expression patterns include $\sim 18$ cells in the ventral regions plus polar staining. The narrow patterns usually include 12-14 cells and have fuzzy borders. Abbreviations: (A) AccI; (B) BamHI; (E) EcoRI; (Na) NaeI; (Nc) NcoI; (P) PvuII; (R) EcoRV; (Ra) RsaI.

rowheads), although the endogenous sna RNA is lost from the poles by the onset of gastrulation. This staining persists during gastrulation and the rapid phase of germ band elongation (Fig. 3B) but is lost shortly thereafter. Expression reappears during neurogenesis and includes all of the neuroblasts that give rise to the central nervous system (CNS) (Fig. 3C). Later, expression is observed in the differentiating neurons of the peripheral nervous system (PNS) (Fig. 3D). These dynamic patterns of neuronal expression are similar to those observed for the endogenous sna gene (Alberga et al. 1991; Kosman et al. 1991; Leptin 1991).

In summary, these results suggest that $2.8 \mathrm{~kb}$ of sna 5 '-flanking sequence contains most of the cis-regulatory elements responsible for both the early and late phases of the normal sna pattern. Hereafter, we focus on the regulation of the early (mesodermal) pattern and no longer consider neuronal expression.

\section{5' Truncations}

A $2.2-\mathrm{kb}$ sna-lacZ fusion gene directs a pattern of expression that is similar, but not identical, to those obtained with the 6- and 2.8-kb promoters. Strong staining is observed in the presumptive mesoderm (Fig. 4A,B) and at the poles, but the lateral limits are slightly narrower and fuzzier than those observed for the larger fusions.
Further deletions cause a narrowing of the pattern and the loss of polar expression. The staining pattern obtained with a 1.6-kb sna-lacZ fusion gene is restricted to the ventral-most 12-14 cells and does not encompass the poles (Figs. 1D and 4C). Thus, the 600 -bp region between -2.2 and $-1.6 \mathrm{~kb}$ appears to be important for directing expression in ventral-lateral regions and the poles. The removal of an additional $300 \mathrm{bp}$ from the $5^{\prime}$ end causes a dramatic reduction in the levels of expression (Fig. 4D). Further 5' deletions, yielding the 900- and 250-bp snalac $Z$ fusion genes, cause an almost complete loss of expression (data not shown). These results suggest that there are at least two regulatory elements located in distal regions of the sna promoter. One of these is located between -2.2 and $-1.6 \mathrm{~kb}$ and is required for expression in polar and ventral-lateral regions. The second element is located between $-1.6 \mathrm{~kb}$ and $-900 \mathrm{bp}$ and is required for activation in ventral regions.

\section{3' Deletions}

The next set of fusion genes that was examined involved deleting $3^{\prime}$ sequences from proximal regions of the sna promoter (summarized in Fig. 2). The $5^{\prime}$ limit of these deletions is at $-2.8 \mathrm{~kb}$, which directs an essentially normal sna pattern when all of the $3^{\prime}$ sequences from the sna promoter are intact. The four 3 ' deletions were at- 


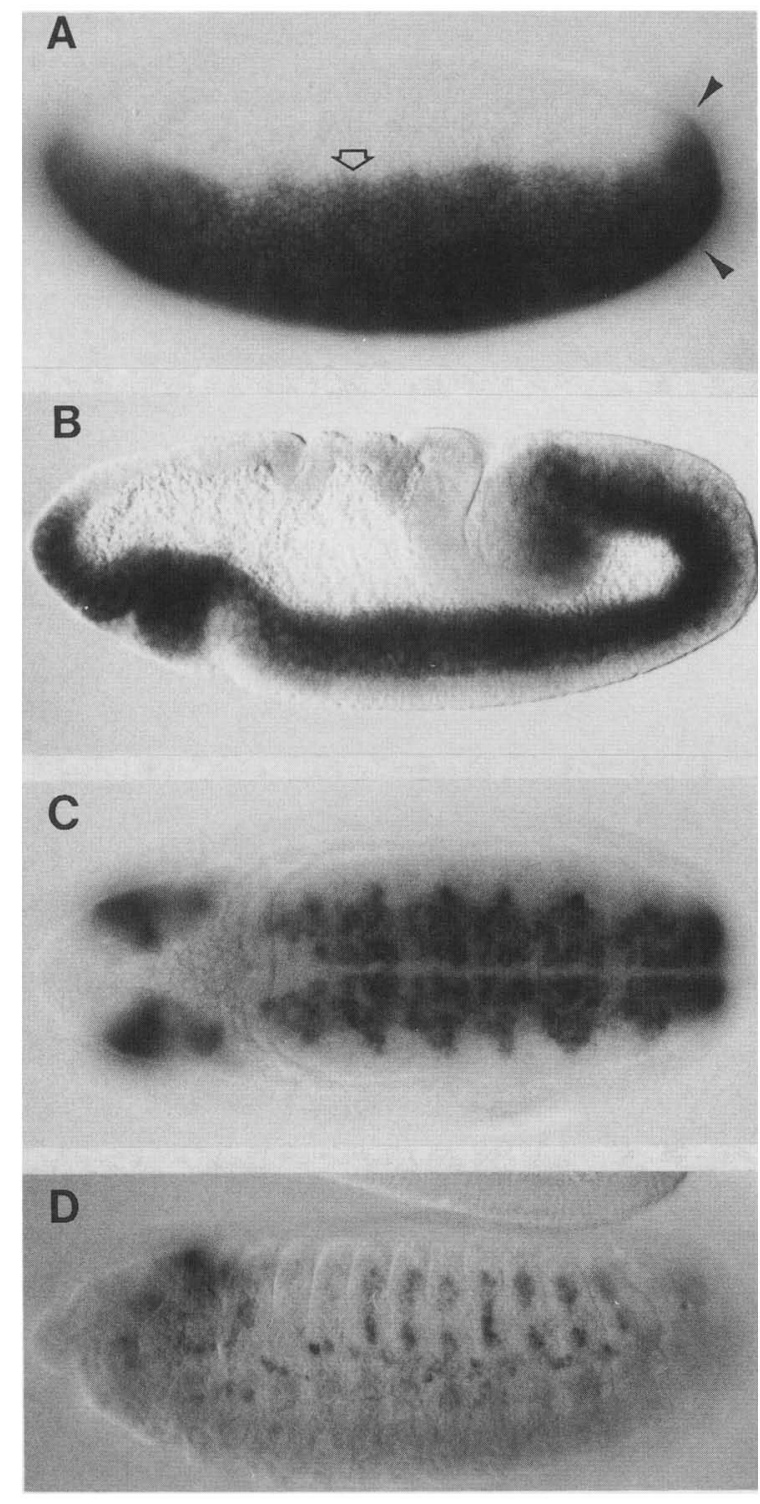

Figure 3. 5'-Flanking sequences can direct an essentially normal sna pattern. Progressively older P-transformed embryos that express either the $6-\mathrm{kb}(A-C)$ or $2.8-\mathrm{kb}(D)$ sna-lacZ fusion gene. The embryos are oriented with anterior to the left, and the staining patterns were determined by in situ hybridization. $(A)$ Ventral-lateral view of a cellularizing P-transformed embryo expressing the 6-kb sna-lac $Z$ fusion gene. The expression pattern spans the entire presumptive mesoderm and shows nearly normal lateral borders (arrow). Expression extends throughout the poles (arrowheads). (B) Lateral view of an elongating embryo expressing the 6-kb $s n a-l a c Z$ fusion gene. Staining is detected throughout the invaginated mesoderm. $(C)$ Dorsal view of an extended embryo expressing the 6-kb fusion gene. By this time, the initial expression in the mesoderm has disappeared, and a new pattern appears in the neurogenic region, which includes all of the segregating neuroblasts. $(D)$ Lateral view of a germband-retracted embryo expressing the $2.8 \mathrm{~kb}$ sna-lac $Z$ fusion gene. Staining is detected in the PNS.

tached to a minimal $h s p 70-1 a c Z$ fusion gene containing only 50 bp of the $h s p 70$ promoter. The first of the $3^{\prime}$ sna deletions that was tested lacks the proximal-most $50 \mathrm{bp}$ of the sna promoter, as well as leader sequences (the W0.05 fusion; see Fig. 2). This sna-hsp70 chimeric promoter directs a pattern of expression that is essentially identical to the one obtained with the $2.8-\mathrm{kb}$ sna-lacZ fusion gene (Fig. 5A). The removal of an additional $50 \mathrm{bp}$ of the sna promoter (W0.1) also has little, if any, effect on the sna pattern (Fig. 5B). These results suggest that the first $100 \mathrm{bp}$ of sna promoter-proximal sequences, such as the TATA box, do not play a specific role in sna regulation.

Further deletions of the sna promoter disrupt reporter gene expression. Deleting an additional $80 \mathrm{bp}$ of the proximal promoter, thereby removing all sequences up to $-180 \mathrm{bp}$ (W0.18), causes a sporadic staining pattern (Fig. 5C). The ventral-lateral limits are not altered, but some of the cells within these limits show little or no staining. The affected cells appear to be randomly distributed within the sna expression domain, with those present in the ventral-most regions showing reduced staining as often as those present in ventral-lateral regions. An even more pronounced salt-and-pepper staining pattern is observed when an addtional $70 \mathrm{bp}$ is removed from the sna promoter (Fig. 5D). In this case, only $10-20 \%$ of the cells within the sna domain show any expression. Interestingly, the ventral-lateral limits do not appear to be altered. The lateral-most cells that are stained (Fig. 5D, arrows) bracket the normal sna pattern, which encompasses a band of $\sim 18$ cells.

In summary, the results obtained by deleting $3^{\prime}$ regions of the sna promoter suggest that there is at least one cis-regulatory element, located between -250 and - 100 bp upstream from the transcription start site, which is essential for ensuring uniformly high levels of expression throughout the sna domain.

\section{Defining the limits of the cis-regulatory elements}

The 5'- and 3'-deletion assays suggest that the sna promoter contains at least three cis-regulatory elements (see Fig. 7C, below). To pinpoint the limits of these elements more accurately, various internal regions of the sna promoter were deleted, and upstream sequences were attached to the minimal $h s p 70$ promoter (see the last set of $1 a c Z$ fusion genes summarized in Fig. 2). The limits of the distal-most element [the polar and lateral activator, [PLA)] were determined by attaching two overlapping 400 -bp regions, from -2 to $-1.6 \mathrm{~kb}$ and -1.9 to -1.5 $\mathrm{kb}$, to a truncated sna-lacZ fusion gene containing just $250 \mathrm{bp}$ of $5^{\prime}$-flanking sequence (the HR-p and TD-p fusions; see Fig. 2). Both direct strong expression at the poles (Fig. 6A), but only the TD-p fusion $(-1.9$ to -1.5$)$ shows broad ventral staining (data not shown). Polar staining was also observed when the -2 - to $-1.6-\mathrm{kb}$ region was attached to the $h s p 70$ minimal promoter / the HR fusion), although there were overall lower levels of expression (data not shown). These results suggest that sna promoter sequences located between -2 and -1.6 $\mathrm{kb}$ are sufficient for polar expression. In addition, a 100bp sequence between -1.6 and $-1.5 \mathrm{~kb}$ is critical for ventral expression. 

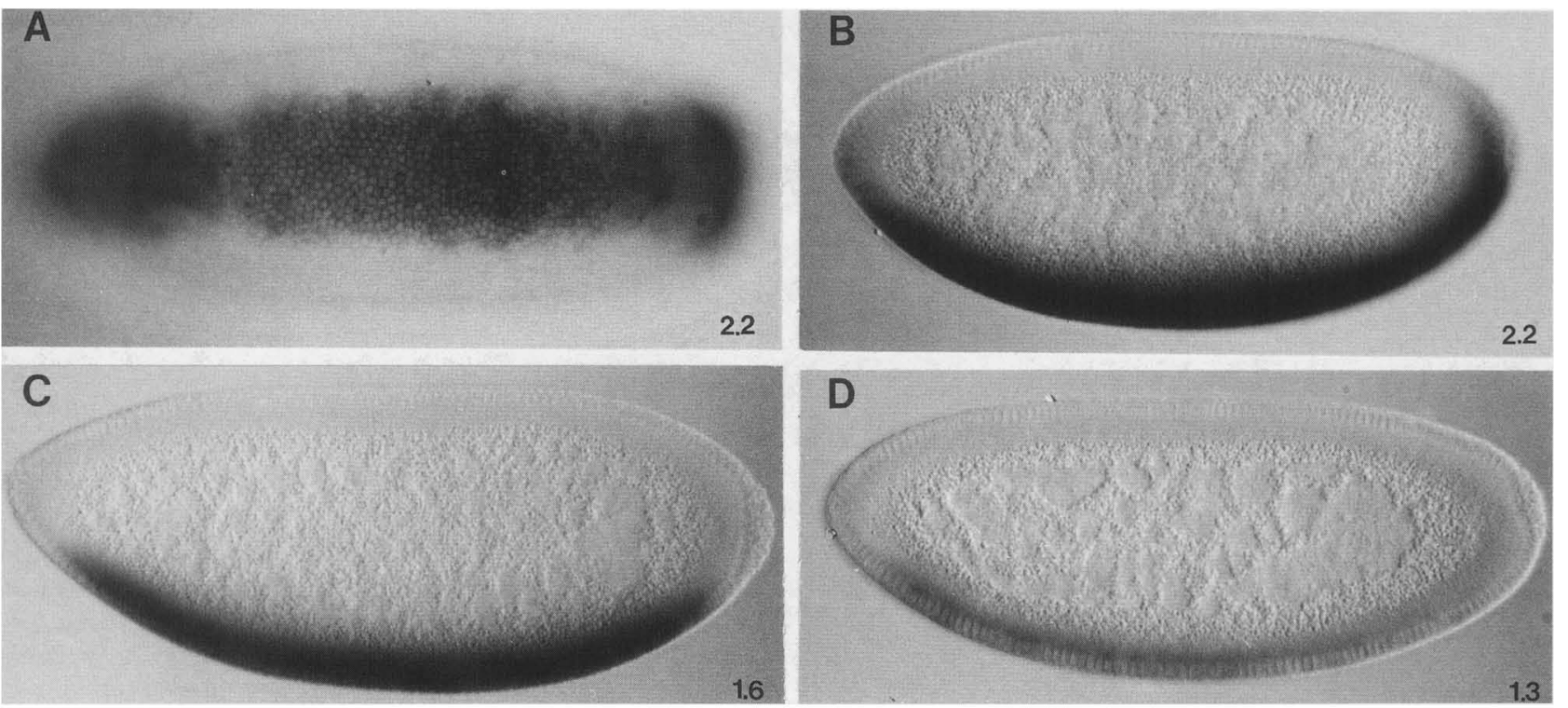

Figure 4. Distal sequences are important for the levels and limits of expression. All embryos are at the nuclear cleavage cycle 14 stage and are oriented with anterior to the left. $A-D$ contain progressive $5^{\prime}$ truncations, as indicated in the lower right corner of each panel (i.e., $A$ and $B$ contain the 2.2-kb sna-lacZ fusion gene). $(A)$ Ventral and $(B)$ lateral views of embryos expressing the 2.2-kb fusion gene. Staining includes nearly the entire presumptive mesoderm $\{\sim 18$ cells $)$, but the borders are fuzzier than those observed for the larger fusion genes or the endogenous sna pattern. $(C)$ Embryo expressing the 1.6-kb sna-lacZ fusion gene. The expression pattern is narrower than normal and includes just the ventral-most 12 cells (see Fig. 1D). Staining does not extend through the poles, as is observed for the larger fusions. $(D)$ Embryo expressing the 1.3-kb fusion gene, which directs very weak staining in the ventral-most 12 cells. Neither of the smaller fusion genes $(900$ and $250 \mathrm{bp}$ ) directs consistent patterns of expression.

The limits of the ventral activation (VA) element were confirmed by attaching sna promoter sequences located between -1.6 and $-1 \mathrm{~kb}$ to both the $h s p 70$ minimal promoter and the -250 -bp truncated sna-lacZ fusion gene (RP and RP-p, respectively; see Fig. 2). There is strong, uniform staining in ventral regions when proximal sna promoter sequences are used (Fig. 6B). Staining includes the ventral-most 12-14 cells but does not extend through the poles. This pattern is very similar to that observed for the truncated 1.6-kb sna-lacZ fusion gene (Fig. 1D), suggesting that sequences located between $-1 \mathrm{~kb}$ and $-250 \mathrm{bp}$ are not required for activation in ventral regions. A sporadic staining pattern was observed when the VA element was attached to the $h s p 70$ minimal promoter (Fig. 6C), rather than proximal sna promoter sequences. These results suggest that optimal expression depends on interactions between the VA element and proximal sequences [the augmentation element (AE)].

The smallest minipromoter that directs a reasonable ventral pattern is only 550 bp in length (the RE-p fusion; Fig. 2) and was obtained by attaching a 300-bp sequence from the VA element (from -1.6 to $-1.3 \mathrm{~kb}$ ) to the 250-bp sna proximal promoter containing the AE. This minipromoter directs expression in the ventral-most 1012 cells (Fig. 6D). The pattern is similar to the one obtained with the intact 600-bp VA element, although staining is not completely uniform, and the ventral-lateral limits are a bit narrower (cf. with Fig. 6B).

DNA-binding assays

As a first step toward determining whether $d l$ and $t w i$ directly regulate sna, DNase I protection assays were done with $d l$ and $t w i$ fusion proteins. The DNA fragments that were used in these experiments span the distal PLA and VA elements ( $-2.2 \mathrm{~kb}$ to $-900 \mathrm{bp}$ ), as well as the proximal $\mathrm{AE}(-250$ to $-100 \mathrm{bp}$ ). The fusion proteins were prepared in the PGEX vector system (Smith and Johnson 1988) and purified on glutathione-affinity beads. A total of $10 \mathrm{dl}$-binding sites were identified in the region from -2 to $-1 \mathrm{~kb}$. An example of the $d \mathrm{l}$-binding assays is shown in Figure 7A. This particular region contains three of the $d l$ sites $(\mathrm{d} 7, \mathrm{~d} 8$, and $\mathrm{d} 9)$. Two twi-binding sites were identified within the AE (Fig. 7B).

The locations and sequences of the $\mathrm{dl}$ - and $t$ wi-binding sites are summarized in Figure 7C. A cluster of four $\mathrm{dl}$ binding sites are located within the limits of the PLA element, whereas six sites occur within or near the VA element. The sequences of these $10 \mathrm{dl}$-binding sites conform to the consensus sequence based on previous studies with zen, twi, and rho promoters (Ip et al. 1991, 1992; Jiang et al. 1991; Pan et al. 1991; Thisse et al. 1991). In general, one of the half-sites includes the sequence GGG, whereas the other half-site contains at least 1 or 2 $\mathrm{C}$ residues. The two half-sites are usually separated by 4 or 5 AT-rich residues. The two twi-binding sites include E-box sequences (CANNTG), although the $t 2$ site is unusual in that it contains two central A residues. Usually, the central residues correspond to $\mathrm{G}$ and/or $\mathrm{C}$ residues (Lenardo et al. 1987).

\section{In vivo relevance of $\mathrm{dl}$ - and twi-binding sites}

Site-directed mutagenesis was done to establish a direct 


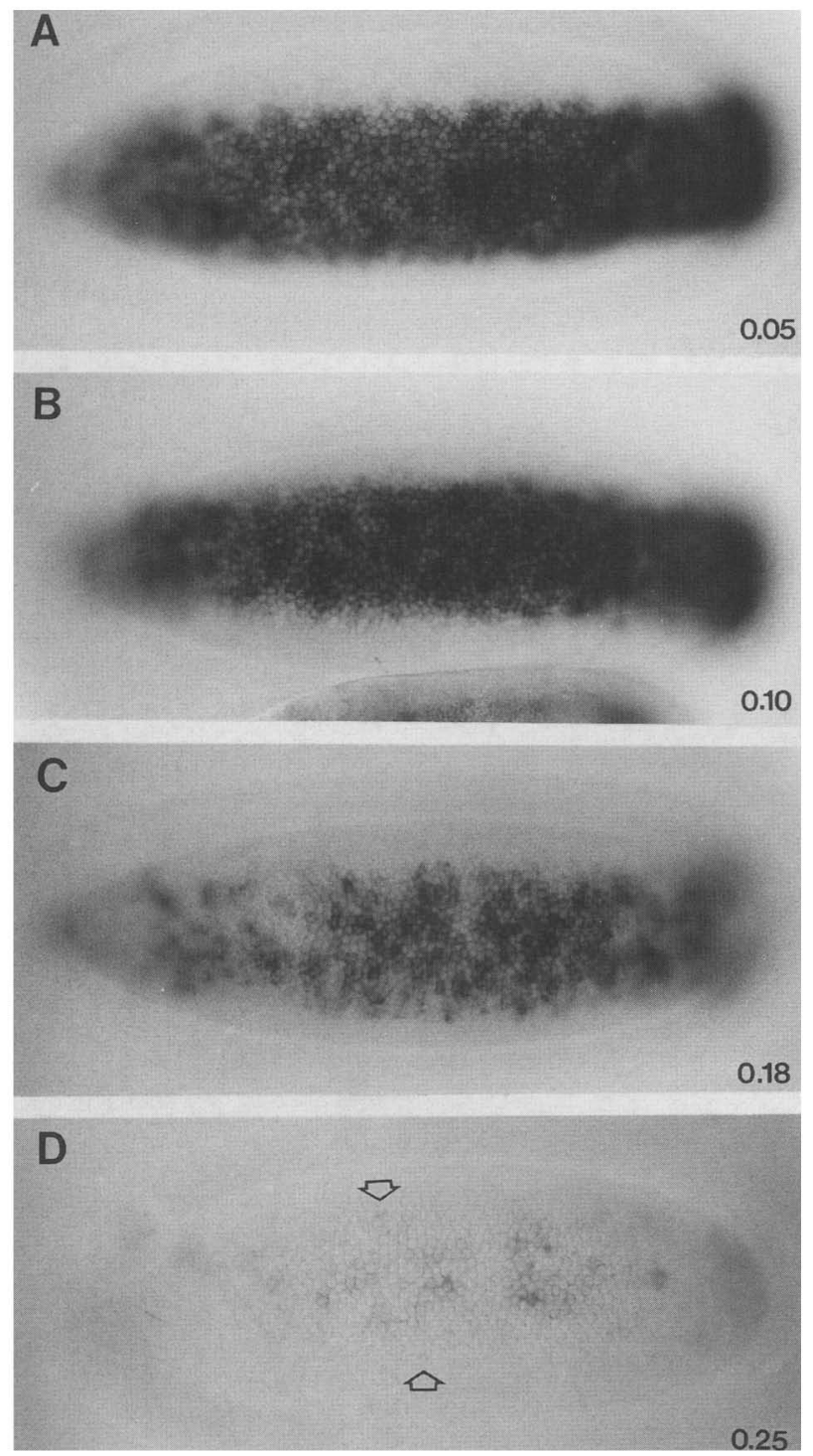

Figure 5. Proximal-promoter sequences are required for optimal expression. All embryos are undergoing cellularization, oriented with anterior to the left, and display ventral views. They contain progressively larger $3^{\prime}$ deletions, as indicated in the lower right corner of each panel (i.e., $A$ lacks the first $50 \mathrm{bp}$ of the proximal promoter). All fusion genes contain the same $5^{\prime}$ site at $-2.8 \mathrm{~kb}$. $(A$ and $B)$ Embryos expressing sna-lac $Z$ fusion genes lacking either 50 or $100 \mathrm{bp}$ of proximal sequences. They direct essentially normal patterns of expression. (C) Embryo expressing a fusion gene lacking the first $180 \mathrm{bp}$ of the sna proximal promoter. There is a disruption in the pattern, in that a significant fraction of cells in the ventral domain are unstained. (D) Embryo expressing the fusion gene lacking the first $250 \mathrm{bp}$ of proximal sequences. There is an even more severe salt-and-pepper pattern, with few cells stained. However, the lateral limits of expression (arrows) appear nearly normal and span the ventral-most $16-18$ cells.

link between individual $d l$ - and $t w i$-binding sites and the genetic regulation of the sna pattern. The first experiments involved disrupting $d l$-binding sites in the PLA, within the context of an otherwise normal $2.8-\mathrm{kb}$ sna$l a c Z$ fusion gene. Mutations in two of the four $d l$ sites (d1 and $\mathrm{d} 4$ ) in the PLA resulted in a staining pattern that does not extend throughout the anterior and posterior poles, as is seen for the wild-type promoter (Fig. 8B; cf. with A). This suggests that polar expression depends on the direct interaction of $d l$ protein present at the poles with the binding sites in the PLA. Interestingly, mutations in the $\mathrm{d} l$ and $\mathrm{d} 4$ sites have no effect on the ventral staining pattern, suggesting that the $d l$ protein present at the poles is functionally distinct from the protein in middle body regions. It is conceivable that these distinct activities involve interactions between $d l$ and the torso (tor) tyrosine kinase activity at the poles. Alternatively, perhaps the tor terminal system controls an unknown regulatory factor that binds near the $d l$ sites and interacts with $d l$ to direct optimal expression at the poles.

The next series of mutations involved the use of the RP-p minipromoter, which contains the 600-bp VA element attached to the 250-bp sna-lac $Z$ fusion gene. This minipromoter contains a total of six $d l$-binding sites (all in the VA) and two twi sites (both in the AE). Mutations in two of the $d l$ sites, $\mathrm{d} 5$ and d10, did not alter the staining pattern driven by the minipromoter (Fig. $8 \mathrm{C}$; cf. with Fig. 6B). However, mutations in five of the six $d l$ sites cause a substantial reduction in expression (data not shown). Mutations that abolish the two twi E boxes in the proximal $\mathrm{AE}$ result in a sporadic salt-and-pepper staining pattern (Fig. 8D). This pattern is similar to those obtained by deleting AE sequences (i.e., Fig. 5C), suggesting that the interaction of the twi protein with the $\mathrm{AE}$ is essential for uniform transcription of the sna promoter throughout the presumptive mesoderm.

Evidence for an interaction between the proximal twibinding sites and the distal $d l$ sites was obtained by creating double mutants. The simultaneous inactivation of the two twi sites in the AE and the $\mathrm{d} 5$ and $\mathrm{d} 10 \mathrm{dl}$ sites in the VA results in a catastrophic reduction in transcription (Fig. 8F; cf. with E). Most P-transformed embryos that carry this mutagenized minipromoter show no staining whatsoever, and the embryo shown in Figure $8 \mathrm{~F}$ is one of the very few that contains residual staining. This result suggests that $d l$ and twi act in concert to activate transcription (see Discussion). Mutations in the two $d l$ sites alone have virtually no effect on the staining pattern (Fig. 8C), probably because the other four $d l$ sites are still intact. Although mutations in the twi sites produce an erratic pattern, the overall levels of expression are not dramatically altered. However, the simultaneous removal of both the $d l$ and $t w i$ sites causes more than a 10 -fold reduction in the levels of expression (cf. Fig. $8 \mathrm{~F}$ with E). Although it is difficult to quantify the absolute levels of expression, it should be noted that all of the sna-lacZ fusion genes shown in Figures 6 and 8 have been stained in parallel, thereby permitting a reasonable estimate of comparative levels of expression.

\section{Discussion}

The establishment of the sna expression pattern is some- 


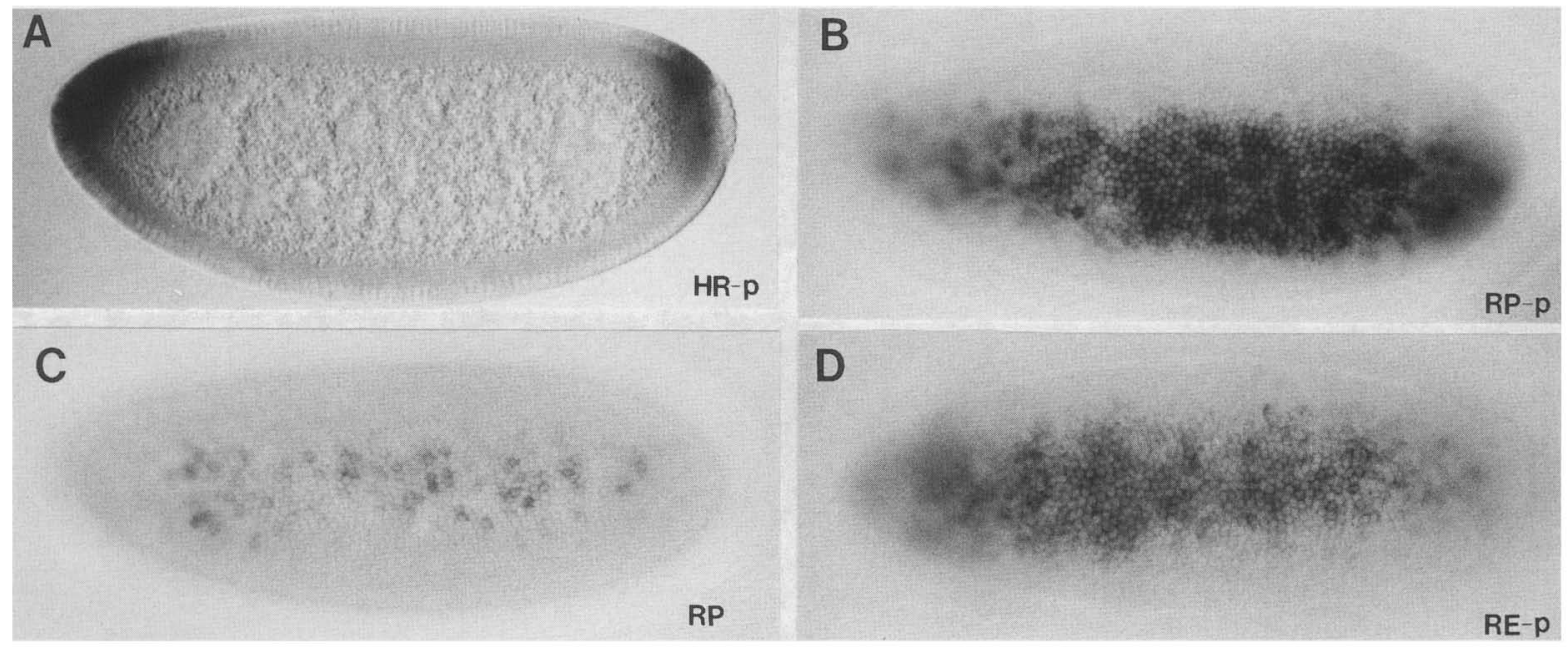

Figure 6. Identification of the three cis-regulatory elements. P-transformed embryos express lac $Z$ fusion genes containing different pieces of the sna promoter. All embryos are at nuclear cleavage cycle 14 and are oriented with anterior to the left. The particular fusion gene that each embryo expresses is indicated at lower right (see Fig. 2 summary). (A) Embryo expressing the HR-p fusion gene, which contains the distal PLA element $(-2$ to $-1.6 \mathrm{~kb})$ attached to proximal sequences spanning the AE. Staining is restricted to the poles. (B) Embryo expressing the RP-p fusion gene, which contains the VA element $(-1.6$ to $-1 \mathrm{~kb})$ attached to proximal AE sequences. Strong staining is observed in the ventral-most 12-14 cells. $(C)$ Embryo expressing the RP fusion gene, which is identical to the one shown in $B$, except that the VA element is attached to the minimal HSP70 promoter rather than the sna proximal AE. A sporadic, salt-and-pepper staining pattern is observed. (D) Embryo expressing the smallest sna minipromoter, which contains a 300-bp region of the VA $(-1.6$ to $-1.3 \mathrm{~kb})$ attached to proximal AE sequences. The expression pattern is weaker and contains fuzzier lateral borders than that obtained when the entire VA $(-1.6$ to $-1 \mathrm{~kb})$ is used.

what different from the regulation of $t w i$ and the interaction of the bicoid $(b c d)$ morphogen with hunchback (hb) (Driever and Nüsslein-Volhard 1989; Struhl et al. 1989). Both the $d l-t w i$ and $b c d-h b$ interactions are responsible for transducing broad gradients into steeper ones. The lateral sna borders are considerably sharper than either the $t w i$ or $h b$ borders and are reminiscent of the on/off anterior margins seen for refined even-skipped and fushi tarazu pair-rule stripes (Frasch et al. 1987; Lawrence et al. 1987). The picture that is emerging for the regulation of sna is summarized in Figure 9. The broad $d l$ concentration gradient triggers the expression of $t w i$, which shows a somewhat steeper gradient than the input $d l$ pattern. This response of twi to $d l$ is probably comparable to the $b c d-h b$ interaction, which has been proposed to involve cooperative interactions of the morphogen with multiple binding sites in the $h b$ promoter (Driever et al. 1989; Struhl et al. 1989). The broad dl gradient then acts in concert with the steeper twi gradient to direct an even sharper sna pattern. The single biggest drop in the steep twi gradient has been shown to coincide with the sna border (Kosman et al. 1991). In principle, the multiplication of the $d l$ and twi slopes could produce a sharp sna border, and the demonstration of a catastrophic reduction in sna expression when both classes of binding sites are disrupted is consistent with this possibility.

\section{dl-twi interactions}

Mutations in $d l$ - and $t w i$-binding sites result in severely reduced levels of expression, although mutations in ei- ther of these sites alone have little or no effect on the sna pattern. The nature of the dl-twi interaction is unknown. It is possible that the two proteins directly contact one another to create an "activation surface" that is qualitatively more efficient in activating transcription than either protein alone. Alternatively, perhaps the two proteins interact independently with different rate-limiting basal factors of the transcription complex. We are currently investigating the possibility that $d l$ and $t w i$ might form multimeric complexes in solution. It is likely that $d l$ interacts with additional activators present in proximal regions of the sna promoter because proximal deletions cause a more severe disruption of the pattern than point mutations in the two twi-binding sites (i.e., cf. Figs. 5D and 8D).

Whatever the nature of the dl-twi interaction, it appears to be essential for driving optimal expression of sna. Interestingly, the $1.2 \mathrm{~kb}$ of $t w i 5^{\prime}$-flanking sequence that is sufficient to direct an essentially normal twi expression pattern (Jiang et al. 1991; Pan et al. 1991; Thisse et al. 1991) lacks general E-box consensus sequences and, in particular, lacks twi-binding sites (R. Park, unpubl.). Thus, it would appear that the differential response of the $t w i$ and sna promoters to the $d l$ concentration gradient involves $d l-t w i$ interactions, which occur for sna but not $t w i$. The $d l-t w i$ interaction is responsible for allowing both high and intermediate levels of $d l$ protein (in ventral vs. ventral-lateral regions) to work equally effectively in activating sna expression. Further support for this view is the pattern of sna expression observed in $t w i^{-}$mutants. The altered sna pattern is quite similar to the initial pattern seen in early wild-type embryos, with 
A

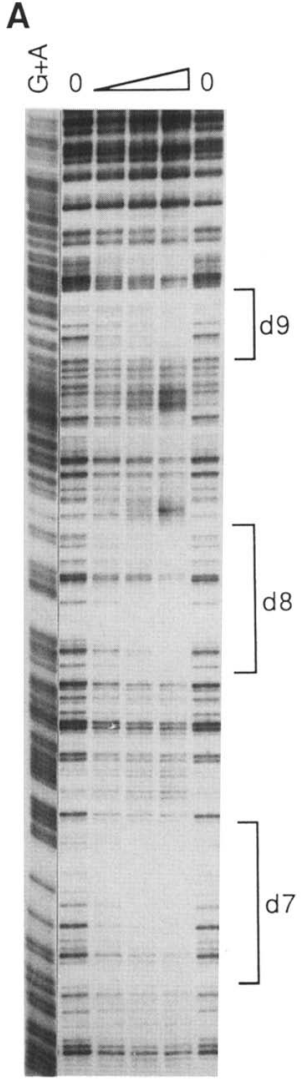

B

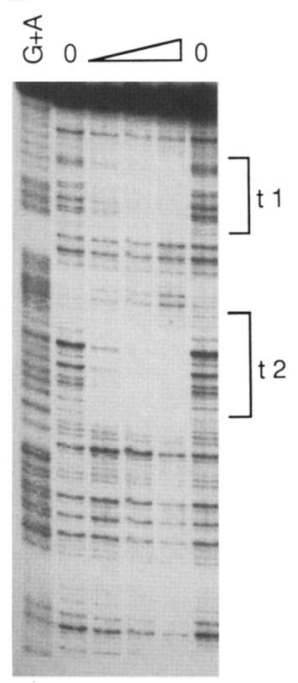

C

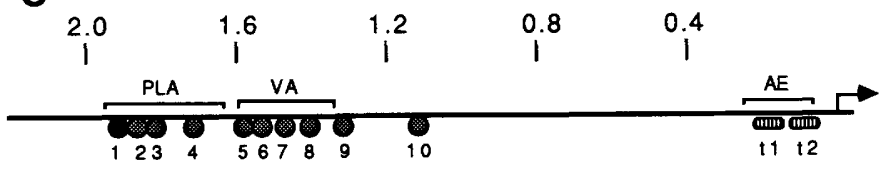

1. AAAGGGTITTCCCCAA

6. TGGGGGTITTCATTAT

2. AAGCGGAAAACACTGG

7. GATGGGAAATTACTTT

3. AGCGGGCCAACCCGAC

8. GCAGGGAAATACGAAA

4. GTGCGGATITCCCGCG

9. AATTGGAATTCCGCGC

5. TCCGGGATGACCCACC

10. GTTGGGAAAGTITCCCATC

Figure 7. Identification of $d l$ and $t$ wi-binding sites. DNase I footprint assays with pGEX-dl and pGEX-twi fusion proteins and DNA fragments from the sna promoter. (A) A 600 -bp DNA fragment corresponding to the VA element $(-1.6$ to $-1 \mathrm{~kb})$ was ${ }^{32}$ P-labeled with Klenow, incubated with increasing amounts of the pGEX-dl fusion protein, digested with DNase I, and electrophoresed on a polyacrylamide-urea gel. Three regions of protection, which correspond to the $\mathrm{d} 7-\mathrm{d} 9 \mathrm{dl}$-binding sites, are shown here. (B) A 200-bp fragment spanning the AE (from -250 to $-50 \mathrm{bp}$ ) was ${ }^{32} \mathrm{P}$-labeled and incubated with increasing amounts of the pGEX-twi fusion protein. There are two regions of protection, which correspond to the $\mathrm{t} 1$ and $\mathrm{t} 2 \mathrm{twi}$-binding sites. (Lanes $G+A$ ) The $G+A$ sequence of the fragment; (lanes 0 ) the digestion patterns without the addition of fusion protein. $(C)$ Summary of the cis-regulatory elements and protein-binding sites. The PLA corresponds to the 400 -bp region from -2 to $-1.6 \mathrm{~kb}$ that is required for expression in polar and ventrallateral regions. The VA element includes the 300 -bp region from -1.6 to $-1.3 \mathrm{~kb}$ and is required for activation in the ventral-most 12 cells. Finally, the proximal AE includes the region from -250 to $-50 \mathrm{bp}$ and is required for strong expression in ventral and ventral-lateral regions. A total of $10 \mathrm{dl}$ - and 2 twi-binding sites were identified within and near these elements. The $\mathrm{d} l$ site has about fivefold higher affinity than the other sites based on gel mobility-shift assays. The sequences of these sites are shown below. Core consensus sequences are underlined.

graded expression in ventral and ventral-lateral regions (see Fig. 1). Sharp on/off patterns of gene expression in mammalian hematopoietic lineages may involve similar interactions, as many B-cell-specific enhancers contain both $\mathrm{E}$ boxes and binding sites for NF-kB (related to $d \mathrm{l}$ ) (Lenardo et al. 1987).

\section{Redundancy of $\mathrm{dl}$-binding sites}

The twi and sna promoters contain a remarkable number of $d l$ activator sites. There are 10 binding sites in the sna promoter and at least 5 (and maybe as many as 10) sites in twi (Jiang et al. 1991; Pan et al. 1991; Thisse et al. 1991). Perhaps activation requires only several binding sites, but the additional sites ensure a reproducible and uniform response to the $d l$ concentration gradient. Alternatively, each $d l$-binding site might be contributing qualitatively distinct aspects of the sna and twi expression patterns. Some of the sites may be important for polar expression, others may mediate activation in ventral regions, and yet others may be required for expression in ventral-lateral regions. The results presented in this study are consistent with both types of models.

Redundancy of the binding sites is suggested by the results obtained with a $2.2-\mathrm{kb}$ sna-lacZ fusion gene bearing a 100-bp internal deletion between -1.6 and $-1.5 \mathrm{~kb}$ (data not shown). This deletion removes the $\mathrm{d} 5$, d6, and d7 dl-binding sites but, nonetheless, has only a minor effect on the levels of expression (at most a twofold reduction as compared with the intact $2.2-\mathrm{kb}$ fusion gene). This observation suggests that the $\mathrm{d} 5-\mathrm{d} 7$ sites are more or less dispensable (see Fig. 7C summary). However, the results obtained with sna minipromoters suggest that the $\mathrm{d} 5, \mathrm{~d} 6$, and $\mathrm{d} 7$ sites directly mediate activation. The 300 -bp region from -1.6 to $-1.3 \mathrm{~kb}$, which contains these three sites, directs strong ventral expression when placed upstream of the proximal AE. Moreover, the 400 bp region from -1.9 to $-1.5 \mathrm{~kb}$ directs weak ventral expression while sequences from -2 to $-1.6 \mathrm{~kb}$ fail to drive such expression, suggesting that the 100 -bp interval containing $d 5-d 7$ is essential for ventral activation.

Not all of the $\mathrm{dl}$-binding sites are interchangeable and direct the same aspects of the sna pattern. For example, the distal-binding sites (d1-d4) are important for mediating expression in ventral-lateral regions where there are only intermediate levels of $d l$ protein. Truncated promoters lacking these binding sites are expressed only in the ventral-most regions where there are peak levels of 
A

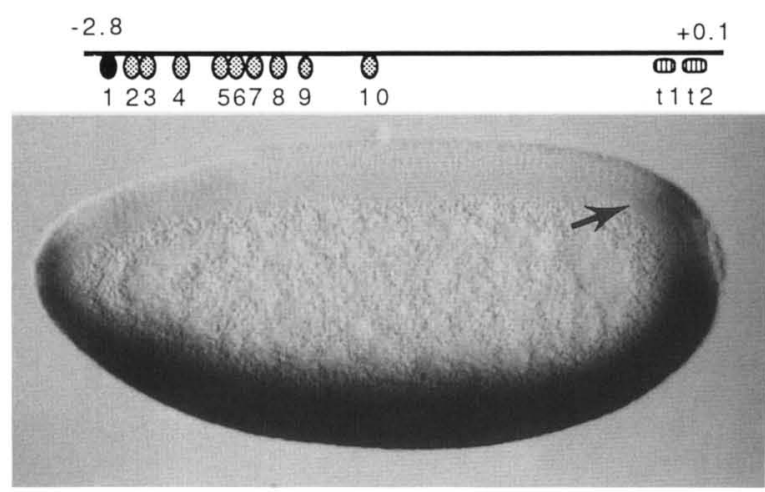

C

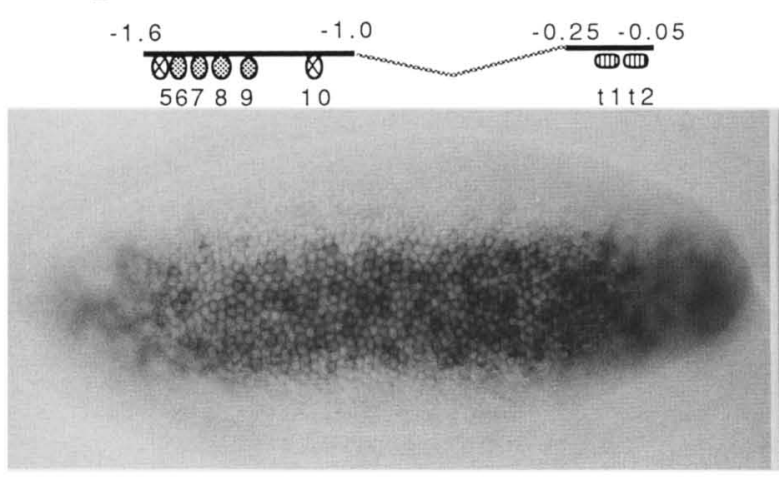

B

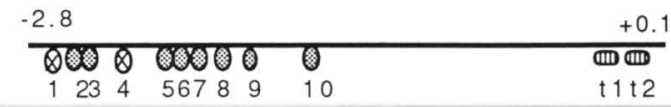

E

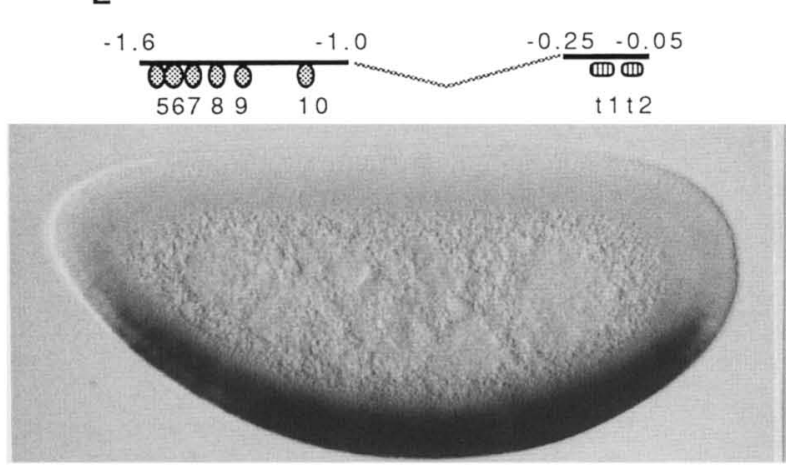

D

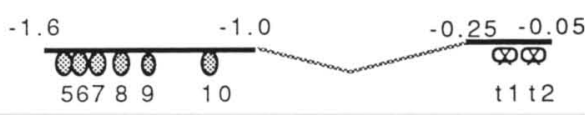

$\mathrm{F}$

$\begin{array}{ccc}-1.6 & -1.0 & -0.25-0.05 \\ 567890 & 0 & t 0\end{array}$

Figure 8. Point mutations in individual $d l$ - and $t w i$-binding sites. P-transformed embryos express various sna-lac $Z$ fusion genes with mutations in individual binding sites. All embryos are oriented with anterior to the left. The diagram above each embryo shows the fusion gene that is expressed and the identities of mutagenized binding sites (indicated by circled $\mathrm{X}$ ). Lateral views of embryos expressing the normal $(A)$ and mutagenized $(B) 2.8-\mathrm{kb}$ sna-lac $Z$ fusion gene are shown. Inactivation of the $\mathrm{d} 1$ and $\mathrm{d} 4 \mathrm{dl}$-binding sites causes reduced expression at the poles (arrows). $(C)$ Ventral view of an embryo expressing the RP-p fusion gene $(-1.6$ to $-1 \mathrm{~kb}$ attached to proximal sequences) containing mutations in two of the six dl-binding sites (d5 and d10). There is no significant change in expression relative to the unmutagenized fusion gene (see Fig. $6 \mathrm{~B}$ ). (D) Ventral view of an embryo expressing the same RP-p fusion gene as in $C$, except that the two twi-binding sites $(\mathbf{t} 1$ and $\mathbf{t} 2)$ were mutagenized instead of the $d l$ sites. This causes a slightly sporadic pattern of expression, but there is only a twofold reduction in the overall levels of staining. $(E)$ Lateral view of an embryo expressing the wild-type RP-p fusion gene. The levels of staining are comparable to that obtained with the 2.8-kb sna-lacZ fusion gene, although expression does not extend to the poles $(\operatorname{see} A$ and $B|| F \mid$. Lateral view of an embryo expressing the RP-p fusion gene containing mutations in both the $d l \mathrm{~d} 5$ and $\mathrm{d} 10$ sites and the $t w i \mathrm{t} 1$ and $\mathrm{t} 2$ sites. Expression is virtually abolished, and the residual staining observed here represents one of the few embryos that shows any expression at all. It was not possible to display a ventral view of this embryo, because such an angle obscures the low levels of staining. Residual staining is amplified in lateral views. 


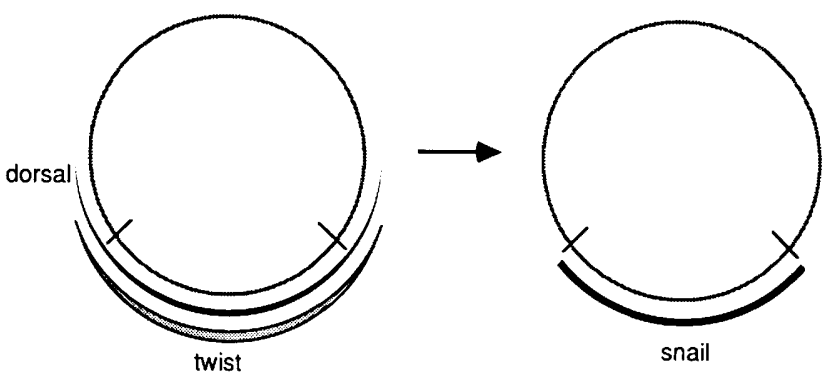

Figure 9. $d l-t w i$ interactions establish the homogeneous, sharp sna expression pattern. The results of genetic analyses and promoter fusion assays suggest that the $d l$ gradient is the primary activator of both twi and sna. twi is expressed in a somewhat steeper gradient than $d l$. $d l$ and twi then act in concert to augment sna expression and establish its sharp on/off pattern.

morphogen. When alone, the distal sites are able to drive expression only at the poles, and for them to mediate expression in ventral-lateral regions, at least three of the more proximal binding sites (d5-d7) must also be present. It is curious that the distal binding sites (such as the high-affinity $\mathrm{dl}$ site) alone are unable to activate transcription, whereas the lower-affinity sites are sufficient for activation. Perhaps the arrangement or spacing of the sites influences $d l$ activity. By analogy to NF- $\mathrm{kB}$ (Baeuerle and Baltimore 1989; Ghosh et al. 1990; Kieran et al. 1990), it is conceivable that $d l$ associates with another, as yet unknown, subunit; the activities of different binding sites might reflect the interactions of $d l$ homo- versus heteromultimers.

\section{Levels vs. limits}

Previous studies on the interaction of the $b c d$ morphogen with the $h b$ promoter led to the suggestion that the affinities of the binding sites are crucial for setting the limits of expression, whereas the total number of sites contribute to the overall levels (Driever et al. 1989; Struhl et al. 1989|. The results presented in this study are essentially consistent with this view. The $10 \mathrm{dl}$-binding sites located in distal regions of the sna promoter are important both for defining the ventral-lateral limits of the pattern and for driving high levels of expression. $5^{\prime}$ Truncations that sequentially remove the $d l$ sites result first in a narrowing of the pattern and, ultimately, in the complete loss of expression. The removal of the distal sites results in a narrowing of the pattern, presumbably because only peak levels of $d l$ (in the ventral-most 10-12 cells) are able to fill the sites present in proximal regions. As observed for $b c d$, it would appear that multiple $d l$ binding sites are required for activation. In the case of sna, a minimum of four sites, $\mathrm{d} 5-\mathrm{d} 8$, are needed for directing relatively strong levels of expression. A truncated promoter containing just two sites, $\mathrm{d} 9$ and $\mathrm{d} 10$, drives only very weak expression. In summary, both $d l$ and $t w i$ are direct activators of sna, and the dl-twi interaction ensures uniform expression of sna in response to the $d l$ gradient. Enhanced expression in ventral-lateral regions is important for establishing the sharp sna border.

\section{Materials and methods}

Molecular cloning

A 300-bp sna cDNA fragment, which includes the $5^{\prime}$ end, was used to screen a $\lambda$ genomic DNA library (see Jiang et al. 1991). The upstream flanking regions were isolated and subcloned for subsequent sequencing. The first $2.8 \mathrm{~kb}$ of 5 '-flanking sequence of the sna promoter was sequenced by use of the Sequenase kit, as suggested by the manufacturer (U.S. Biochemical, Cleveland $\mathrm{OH})$.

\section{Construction of transformation plasmids}

The experiments described in this study involved the use of two different injection vectors, $\mathrm{pCaSper}-\mathrm{AUGbetagal}$ (Thummel et al.1988) and pWHL (see Driever et al. 1989). Both contain the white gene as a marker. The first vector contains the alcohol dehydrogenase translation initiation sequences. The sna $5^{\prime}$ truncation series (see Fig. 2) includes the sna transcription start site and the first $100 \mathrm{bp}$ of untranslated leader sequence. sna promoter fragments containing either 6 or $3 \mathrm{~kb}$ of $5^{\prime}$-flanking sequence were first subcloned into the pGEM7Zf $|+|$ plasmid (Promega, Madison WI). The $5^{\prime}$ ends of the various fragments are indicated in the legend to Figure 2, and the $3^{\prime}$ ends used the unique KpnI site in the polylinker of the vector. The fragments were cloned into the P-transformation vectors after digestion with BamHI and KpnI; the BamHI site was blunted when necessary. The pWHL vector contains the HSP70 minimal TATA element, and the sna fragments were directly blunt-end ligated into the StuI site upstream of the promoter. The internal deletions were prepared by sequential cloning of the fragments into the pGEM7 vectors, and the fusion promoters were then ligated into the transformation plasmid.

\section{Site-directed mutagenesis}

The appropriate sna pGEM7 subclones were transformed into the CJ236 strain of Escherichia coli to obtain single-stranded DNA templates containing uracil. The mutant oligonucleotides were annealed, and the complementary strands were synthesized in vitro by use of T4 polymerase, as suggested by the manufacturer (Bio-Rad Muta-gene kit). The double-stranded plasmids were transformed into the DH5a strain, and the mutated DNAs were confirmed by sequence analysis. The relevant sequences of the mutagenic oligonucleotides are as follows: $\mathrm{d} 1$, AAAGAGCTCTACAGAA; d4, GTGCGCATGCGTGCGC; d5, TCCTAGATGGTTAACC; d10, GTTGTAAAAGGTATGCATC; t1, CGCAAAGCTTCGAG; t2, CCACAATATTGCGA. The bold nucleotides correspond to the mutagenic substitutions.

\section{Detection of reporter gene expression}

At least two, and usually three, independent transformants were examined for each sna fusion gene tested in this study. Appropriately staged P-transformed embryos were fixed with formaldehyde and stained for $l a c Z$ reporter gene expression by use of the digoxygenin-detection system (Boehringer Mannheim) as described previously (Jiang et al. 1991). An antisense lac $Z$ riboprobe was hybridized with whole-mount preparations of P-transformed embryos, and the expression patterns were vi- 
sualized with a histochemical staining method (anti-digoxygenin antibodies conjugated to alkaline phosphatase).

\section{DNA-binding assays}

$d l$ and $t w i$ fusion proteins were prepared from bacterial extracts by use of the pGEXKG expression vector, which contains glutathione S-transferase (Smith and Johnson 1988). The dl-pGEX fusion gene was made with a $1.2-\mathrm{kb}$ NdeI-SacI $d l$ cDNA fragment, which was obtained from the pARdl-378 T7 expression plasmid described by Ip et al. (1991). This DNA fragment encodes the amino-terminal 378-amino-acid residues of the $\mathrm{dl}$ protein, which includes the entire rel/NF- $\mathrm{B}$ homology region. The fragment was blunt-ended with T4 DNA polymerase and inserted into the SmaI site of the pGEX vector. The pGEX-twi fusion protein was prepared by inserting a $1.6-\mathrm{kb}$ NdeI-EcoRI $t w i$ cDNA fragment into the expression vector. This fragment was obtained from a pAR T7 expression plasmid containing the entire twi-coding sequence (D. Kosman, unpubl.). The $t$ wi fragment obtained from this $\mathrm{T} 7$ recombinant was blunted and inserted into the SmaI site of the pGEX vector. Fusion proteins were prepared as described (Smith and Johnson 1988), with the following modifications. Induced bacteria were pelleted by centrifugation and resuspended in $1 / 50$ volume of lysis buffer $125 \mathrm{~mm}$ HEPES at $\mathrm{pH} 7.5,20 \mathrm{~mm} \mathrm{KCl}, 2.5 \mathrm{~mm}$ EDTA, $1 \%$ Triton X-100, $1 \mathrm{mM}$ DTT, $0.5 \mathrm{~mm}$ PMSF, $1 \mu \mathrm{g} / \mathrm{ml}$ of pepstatin, $1 \mu \mathrm{g} / \mathrm{ml}$ of leupeptin|. Resuspended bacteria were subjected to three freeze-thaw cycles and then sonicated for $30 \mathrm{sec}$. A $1 / 10$ volume of $5 \mathrm{M} \mathrm{NaCl}$ was added and placed on ice for $15 \mathrm{~min}$. The lysate was spun at $12,000 \mathrm{~g}$ for $15 \mathrm{~min}$ at $4^{\circ} \mathrm{C}$. Fusion proteins were affinity purified by adding $1 / 10$ volume of glutathione-agarose beads (Sigma) and incubating for $1 \mathrm{hr}$ at $4^{\circ} \mathrm{C}$. The beads were pelleted by centrifugation and washed three times with 20 volumes of lysis buffer and once with 20 volumes of $50 \mathrm{~mm}$ Tris $(\mathrm{pH} 8)$. Fusion proteins were eluted from the beads by the addition of 1 volume of $50 \mathrm{~mm}$ Tris $(\mathrm{pH} 8), 10 \mathrm{~mm}$ glutathione. The glutathione was removed by dialyzing three times against 250 volumes of buffer $\mathrm{B}$ ( $25 \mathrm{~mm} \mathrm{HEPES}$ at $\mathrm{pH} 7.5,50 \mathrm{mM} \mathrm{KCl}, 1 \mathrm{~mm}$ DTT, $1 \mathrm{~mm}$ EDTA; $6 \mathrm{mM} \mathrm{MgCl}_{2}, 10 \%$ glycerol|, and the protein was stored at $-70^{\circ} \mathrm{C}$. DNase I footprinting was done essentially as described by Hoey and Levine (1988). sna promoter sequences located between -2.0 and $-1.6 \mathrm{~kb},-1.6$ and $-1.0 \mathrm{~kb}$, and -250 and -50 bp were ${ }^{32} \mathrm{P}$-labeled with Klenow and gel purified. Binding reactions were done with pGEX fusion proteins and $100,000 \mathrm{cpm}$ of labeled DNA in $50 \mu \mathrm{l}$ of footprinting buffer (25 mM HEPES at pH 7.5, $50 \mathrm{mM} \mathrm{KCl}, 3 \mathrm{~mm} \mathrm{MgCl}_{2}, 1 \mathrm{~mm}$ EDTA, $0.5 \%$ NP- $40,10 \mu \mathrm{g} / \mathrm{ml}$ of poly[d(I-C)], $10 \%$ glycerol).

\section{Acknowledgments}

This work was funded by a grant from the National Institutes of Health (GM 46638). Y.T.I. is a Hoffmann-La Roche fellow of the Life Sciences Research Foundation.

The publication costs of this article were defrayed in part by payment of page charges. This article must therefore be hereby marked "advertisement" in accordance with 18 USC section 1734 solely to indicate this fact.

\section{References}

Alberga, A., J.-L. Boulay, E. Kempe, C. Dennefeld, and M. Haenlin. 1991. The snail gene required for mesoderm formation in Drosophila is expressed dynamically in derivatives of all three germ layers. Development 111: 983-992.

Baeuerle, P.A. and D. Baltimore. 1989. A $65-\mathrm{kD}$ subunit of ac- tive NF- $\mathrm{BB}$ is required for inhibition of NF- $\mathrm{BB}$ by IкB transcription. Genes \& Dev. 3: 1689-1698.

Boulay, J.-L., C. Dennefeld, and A. Alberga. 1987. The Drosophila developmental gene snail encodes a protein with nucleic acid binding fingers. Nature 330: 395-398.

Doyle, H.J., K. Harding, T. Hoey, and M. Levine. 1986. Transcripts encoded by a homeobox gene are restricted to dorsal tissues of Drosophila embryos. Nature 323: 76-79.

Doyle, H.J., R. Kraut, and M. Levine. 1989. Spatial regulation of zerknüllt: A dorsal-ventral patterning gene in Drosophila. Genes \& Dev. 3: 1515-1533.

Driever, W. and C. Nüsslein-Volhard. 1989. The bicoid protein is a positive regulator of hunchback transcription in the early Drosophila embryo. Nature 337: 138-143.

Driever, W., G. Thoma, and C. Nüsslein-Volhard. 1989. Determination of spatial domains of zygotic gene expression in the Drosophila embryo by the affinity of binding sites for the bicoid morphogen. Nature 340: 363-367.

Frasch, M., T. Hoey, C. Rushlow, H. Doyle, and M. Levine. 1987. Characterization and localization of the even-skipped protein of Drosophila. EMBO J. 6: 749-759.

Ghosh, S., A.M. Giffod, L.R. Riviere, P. Tempst, G.P. Nolan, and D. Baltimore, 1990. Cloning of the p50 DNA binding subunit of NF-kB: Homology to rel and dorsal. Cell 62: 1019-1029.

Govind, S. and R. Steward. 1991. Dorsoventral pattern formation in Drosophila. Trends Genet. 7: 119-125.

Hashimoto, C., K.L. Hudson, and K.V. Anderson. 1988. The Toll gene of Drosophila, required for dorsal-ventral embryonic polarity, appears to encode a transmembrane protein. Cell 52: $269-279$.

Hoey, T. and M. Levine. 1988. Divergent homeo box proteins recognize similar DNA sequences in Drosophila. Nature 331: 858-861.

Ip, Y.T. and M. Levine. 1992. The role of the dorsal morphogen gradient in Drosophila embryogenesis. Sem. Dev. Biol. 3: 15-23.

Ip, Y.T., R.E. Park, D. Kosman, E. Bier, and M. Levine. 1992. The dorsal gradient morphogen regulates stripes of rhomboid expression in the presumptive neuroectoderm of the Drosophila embryo. Gene \& Dev. (in press).

Ip, Y.T., R. Kraut, M. Levine, and C.A. Rushlow. 1991. The dorsal morphogen is a sequence-specific DNA-binding protein that interacts with a long-range repression element in Drosophila. Cell 64: 439-446.

Jiang, J., D. Kosman, Y.T. Ip, and M. Levine. 1991. The dorsal morphogen gradient regulates the mesoderm determinant twist in early Drosophila embryos. Genes \& Dev. 5: 18811891.

Jiang, J., C.A. Rushlow, S.J. Small, and M. Levine. 1992. Individual $d l$ binding sites mediate activation and repression in Drosophila embryos. EMBO J. 8 (in press).

Kasai, Y., J.R. Nambu, P.M. Lieberman, and S.T. Crews. 1992. Dorsal-ventral pattern in Drosophila: DNA binding of snail protein to the single-minded gene. Proc. Natl. Acad. Sci. 89: 3414-3418.

Kieran, M., V. Blank, F. Logeat, J. Vandekerckhove, F. Lottspeich, O. Le Bail, M.B. Urban, P. Kourilsky, P.A. Baeuerle, and A. Israel. 1990. The DNA binding subunit of NF-kB is identical to factor KBFl and homologous to the rel oncogene product. Cell 62: 1007-1018.

Kosman, D., Y.T. Ip, M. Levine, and K. Arora. 1991. Establishment of the mesoderm-neuroectoderm boundary in the Drosophila embryo. Science 254: 118-122.

Lawrence, P., P. Johnston, P. Macdonald, and G. Struhl. 1987. Borders of parasegments in Drosophila are delimited by the fushi tarazu and even-skipped genes. Nature 328: 440-442. 
Ip et al.

Lenardo, M., J.W. Pierce, and D. Baltimore. 1987. Protein-binding sites in Ig gene enhancers determine transcriptional activity and inducibility. Science 236: 1573-1577.

Leptin, M. 1991. twist and snail as positive and negative regulators during Drosophila mesoderm development. Genes \& Dev. 5: 1568-1576.

Leptin, M. and B. Grunewald. 1990. Cell shape changes during gastrulation in Drosophila. Development 110: 73-84.

Michelson, A.M., S.M. Abmayr, M. Bate, M. Martinez-Arias, and T. Maniatis. 1990. Expression of a MyoD family member prefigures muscle pattern in Drosophila embryos. Genes \& Dev. 4: 2086-2097.

Murre, C., P.S. McCaw, and D. Baltimore. 1989.. A new DNA binding and dimerization motif in immunoglobulin enhancer binding, daughterless, MyoD, and myc proteins. Cell 56: $777-783$.

Nambu, J.R., R.G. Franks, S. Hu, and S.T. Crews. 1990. The single-minded gene of Drosophila is required for the expression of genes important for the development of CNS midline cells. Cell 63: 63-75.

Pan, D., J.-D. Huang, and A.J. Courey. 1991. Functional analysis of the Drosophila twist promoter reveals a dorsal-binding ventral activator region. Genes \& Dev. 5: 1892-1901.

Rao, Y., H. Vaessin, L.Y. Jan, and Y.-N. Jan. 1991. Neuroectoderm in Drosophila embryos is dependent on the mesoderm for positioning but not for formation. Genes \& Dev. 5: $1577-$ 1588.

Ray, R., K. Arora, C. Nüsslein-Volhard, and W.M. Gelbart. 1991. The control of cell fate along the dorsal-ventral axis of the Drosophila embryo. Development 113: 35-54.

Roth, S., D. Stein, and C. Nüsslein-Volhard. 1989. A gradient of nuclear localization of the dorsal protein determines dorsoventral pattern in the Drosophila embryo. Cell 59: 11891202.

Rushlow, C.A., M. Frasch, H. Doyle, and M. Levine. 1987. Maternal regulation of zerknüllt: A homeobox gene controlling differentiation of dorsal tissues in Drosophila. Nature 330: $583-586$.

Rushlow, C.A., K. Han, J.L. Manley, and M. Levine. 1989. The graded distribution of the dorsal morphogen is initiated by selective nuclear transport in Drosophila. Cell 59: 11651177.

St. Johnston, R.D. and W.M. Gelbart. 1987. decapentaplegic transcripts are localized along the dorsal-ventral axis of the Drosophila embryo. EMBO 1. 6: 2785-2791.

St. Johnston, D. and C. Nüsslein-Volhard. 1992. The origin of pattern and polarity in the Drosophila embryo. Cell 68: 201219.

Shimell, M.J., E.L. Ferguson, S.R. Childs, and M.B. O'Connor. 1991. The Drosophila dorsal-ventral patterning gene tolloid is related to human bone morphogenetic protein 1. Cell 67: 469-481.

Smith, D.B. and K.S. Johnson. 1988. Single-step purification of polypeptides expressed in E. coli as fusions with glutathione S-transferase. Gene 67: 31-40.

Stein, D., S. Roth, E. Vogelsang, and C. Nüsslein-Volhard. 1991. The polarity of the dorsoventral axis in the Drosophila embryo is defined by an extracellular signal. Cell 65: 725-735.

Steward, R. 1989. Relocalization of the dorsal protein from the cytoplasm to the nucleus correlates with its function. Cell 59: 1179-1188.

Struhl, G., K. Struhl, and P.M. Macdonald. 1989. The gradient morphogen bicoid is a concentration-dependent transcriptional activator. Cell 57: 1259-1273.

Thisse, B., C. Stoetzel, M.E. Messal, and F. Perrin-Schmitt. 1987. Genes of the Drosophila maternal dorsal group control the specific expression of the zygotic gene twist in presumptive mesodermal cells. Genes \& Dev. 1: 709-715.

Thisse, B., C. Stoetzel, C. Gorostiza, and F. Perrin-Schmitt. 1988. Sequence of the twist gene and nuclear localization of its protein in endomesodermal cells of early Drosophila embryos. EMBO I. 7: 2175-2183.

Thisse, C., F. Perrin-Schmitt, C. Stoetzel, and B. Thisse. 1991. Sequence-specific transactivation of the Drosophila twist gene by the dorsal gene product. Cell 65: 1191-1201.

Thummel, C.S., A.M. Boulet, and H.D. Lipshitz. 1988. Vectors for Drosophila P-element-mediated transformation and tissue culture transformation. Gene 74: 445-456. 


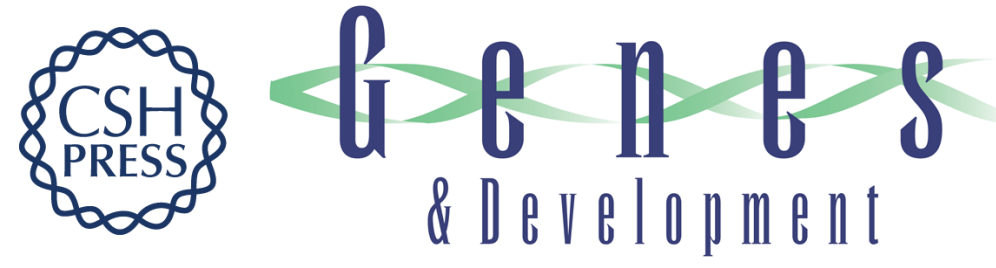

\section{dorsal-twist interactions establish snail expression in the presumptive mesoderm of the Drosophila embryo.}

Y T Ip, R E Park, D Kosman, et al.

Genes Dev. 1992, 6:

Access the most recent version at doi:10.1101/gad.6.8.1518

References This article cites 42 articles, 13 of which can be accessed free at: http://genesdev.cshlp.org/content/6/8/1518.full.html\#ref-list-1

License

Email Alerting

Service

Receive free email alerts when new articles cite this article - sign up in the box at the top right corner of the article or click here.

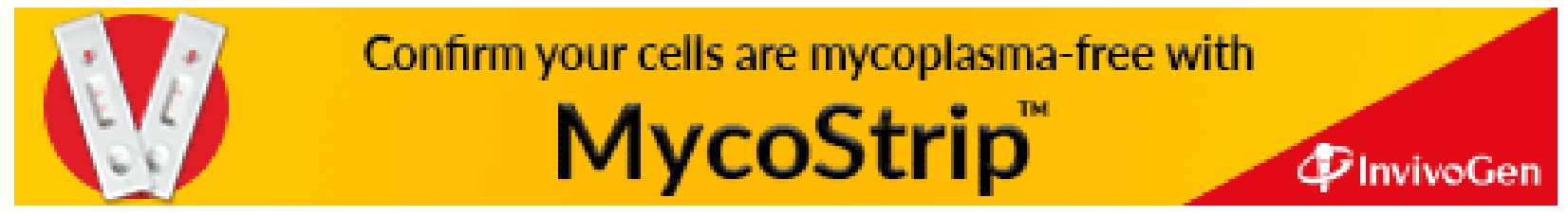

